\title{
Biomaterials
}

\section{Preparation of a biphasic porous bioceramic by heating bovine cancellous bone with $\mathrm{Na}_{4} \mathrm{P}_{2} \mathrm{O}_{7} \cdot 10 \mathrm{H}_{2} \mathrm{O}$ addition}

\author{
Feng-Huei Lin ${ }^{a}$, Chun-Jen Liao ${ }^{\text {a }}$ Ko-Shao Chen ${ }^{\mathrm{b}}$, Jui-Sheng Sun ${ }^{\mathrm{c}, *}$ \\ ${ }^{a}$ Institute of Biomedical Engineering, College of Medicine, National Taiwan University, Taipei, Taiwan, ROC \\ ${ }^{\mathrm{b}}$ Department of Material Engineering, Tatung Technology Institute, Taipei, Taiwan, ROC \\ ${ }^{c}$ Department of Orthopaedic Surgery, College of Medicine, National Taiwan University, Taipei, Taiwan, ROC
}

Received 2 March 1998; accepted 15 September 1998

\begin{abstract}
Sintered bovine cancellous bone exhibited excellent biocompatiblity, high porosity and have an interconnecting porous structure allowing for bone ingrowth. However, the main mineral constitution of sintered bovine bone-hydroxyapatite $\left(\mathrm{Ca}_{10}\left(\mathrm{PO}_{4}\right)_{6}(\mathrm{OH})_{2}\right.$, HAP) seems to be too stable in vivo. For improving its bioactivity, the calcined bovine bone-removing the organic substance by burning process - with different quantities of sodium pyrophosphate $\left(\mathrm{Na}_{4} \mathrm{P}_{2} \mathrm{O}_{7} \cdot 10 \mathrm{H}_{2} \mathrm{O}\right.$, NP) addition was heated to a high temperature to transform its crystalline phase constitution from HAP into TCP/HAP biphasic or other multiphasic structures Results revealed that the calcined bovine bone without NP addition, exhibited a pure form of HAP characterized pattern during heating. Its thermal behavior was similar to stoichiometric $\mathrm{HAP}$, it gradually lost its $\mathrm{OH}^{-}$ions and transformed into oxyhydroxyapatite at high temperature. After being doped into calcined bovine bone, NP would react with HAP to form $\beta \mathrm{TCP}$ and $\mathrm{NaCaPO}_{4}$ around $600^{\circ} \mathrm{C}$. At $900^{\circ} \mathrm{C}$, doped $\mathrm{NP}$ would completely react with $\mathrm{HAP}$ and the $\mathrm{NaCaPO}_{4}$ would further react with $\mathrm{HAP}$ to form more $\beta$ TCP in the system. With NP increasing in the calcined bovine bone, HAP would gradually convert into different crystalline phase compositions of TCP/HAP, TCP $/ \mathrm{HAP} / \mathrm{NaCaPO}_{4}$ or TCP $/ \mathrm{NaCaPO}_{4}$ at high temperature. By heating calcined bovine cancellouse bone with different quantities of NP we could obtain different crystalline phase compositions of natural porous bioceramic in this study. (C) 1999 Elsevier Science Ltd. All rights reserved
\end{abstract}

Keywords: Biphasic calcium phosphate; Bioceramic; Xenogeneic bone

\section{Introduction}

Xenogeneic bone has long been used as a bone grafting material. It is easy to obtain and has lower cost than autogeneic or allogeneic bone graft. However, the clinical application of xenograft has been limited because it involved numerous problems such as infection, disease transfer, and immunological defensive reaction $[1,2]$. To overcome these problems, various treatments have been tried with the aim of removing the strongly antigenic proteins and the cellular elements of xenogeneic bone. The Kiel bone splinter, was developed by Martz and Bauermeister et al. $[3,4]$, using the special maceration process to destroy the protein of bovine bone. Clinically,

\footnotetext{
*Corresponding author. Fax: +886223940049; e-mail: double@ ha. mc.nut.edu.tw
}

Kiel bone has been used in orthopedic surgery for filling bone defects [5], but the results of Kiel bone application were still controversial since the deproteination of Kiel bone was incomplete which might have evoked the immuno-defensive reaction [6]. Recently, a pure mineral bone has been developed, removing all organic components of bovine bone and sintering remnant mineral constitution by high-temperature heat-treatment $[1,2]$. The sintered cancellous bone maintained the spongy structure of natural bone, which has an interconnecting porous structure, high porosity (about $70 \mathrm{vol} \%$ ), and a character of osteoconduction allowing for bone ingrowth to form an osseous bed. In comparison to the synthetic porous ceramics, the sintered cancellous bone seems superior to the synthetic porous ceramics. Since the porous calcium phosphate ceramics, using the usual foaming process, has numerous closed pores and bubbly fan walls, the invasion of bone tissue deep into the material would be hampered. Thus, the sintered cancellous 
bone with an exceptional porous structure has attracted more and more attention in recent years.

The crystalline phase composition of sintered bovine cancellous bone is similar to natural bone mineralmainly hydroxyapatite $\left(\mathrm{Ca}_{10}\left(\mathrm{PO}_{4}\right)_{6}(\mathrm{OH})_{2}, \mathrm{HAP}\right)$ about $93 \mathrm{wt} \%$ and consists of about $7 \mathrm{wt} \%$ of $\beta$-tricalcium phosphate $\left(\mathrm{Ca}_{3}\left(\mathrm{PO}_{4}\right)_{2}, \beta \mathrm{TCP}\right)[1,2]$. HAP has excellent biocompatiblity, faster bone regeneration, and direct bonding to regenerated bone without intermediate connective tissue [7-9]. However, HAP seems to be too stable in vivo because it shows a similar crystalline phase as bone mineral, which will tend toward chemical and biological equilibrium with bone tissue. $\beta$ TCP had greater extent dissolution and degradation than those of HAP [9], but some investigators reported that the rate of degradation of $\beta \mathrm{TCP}$ was too fast for optimum bonding to bone [10]. A recent study claimed that the biphasic calcium phosphate (BCP) ceramics, consisting of a mixture of $\beta \mathrm{TCP}$ and HAP, i.e. the weight ratio of $30 / 70$ or $40 / 60$ of $\beta \mathrm{TCP} / \mathrm{HAP}$ ceramics, have demonstrated more efficiency in the repair of bone defects than pure HAP or pure $\beta$ TCP ceramic alone [10-12].

In the study, we tried to develop series of TCP/HAP biphasic calcium phosphates with natural bone structure of interlocking pores that would make physiological fluid deep into the material and provide an osseous bed for bone ingrowth. In our previous study, deficient hydroxyapatite (d-HAP) doped with sodium pyrophosphate $\left(\mathrm{Na}_{4} \mathrm{P}_{2} \mathrm{O}_{7} \cdot 10 \mathrm{H}_{2} \mathrm{O}\right.$, NP) could partially convert d-HAP into $\beta$ TCP on heating to a temperature up to $600^{\circ} \mathrm{C}$. With different NP addition, we could prepare series of TCP/HAP biphasic calcium phosphates in different ratios. Calcined bovine bone was immersed into the NP solution and then heated at an appropriate temperature for sintering and phase transformation. By doping NP into calcined bovine bone (CBB), HAP was partially converted into $\beta \mathrm{TCP}$ at high temperature and $\mathrm{TCP} /$ HAP biphasic calcium phosphate bioceramics with a natural bovine bone structure were successfully prepared.

In the present study, we used X-ray diffraction (XRD) analysis to examine the phase transformation of the materials at different heating temperatures. The functional group of $\mathrm{CBB}$ and $\mathrm{CBB}$ with NP addition at different temperatures were traced by a Fourier-transformed infrared (FTIR) spectroscope. The phase transformation and crystal structure reconstruction of $\mathrm{CBB}$ with different NP additions at different heating temperatures were also described in this study.

\section{Materials and methods}

\subsection{Preparation of the specimens}

Cancellous bone was obtained from calf femoral condyles and cut into small cubes of approximately $1 \mathrm{~cm}^{3}$. In order to avoid the cracking and soot formation in the material during the heat-treatment process, the raw bone was boiled in distilled water for $12 \mathrm{~h}$. After boiling, the cancellous bone blocks were dehydrated in an alcohol series and dried at $70^{\circ} \mathrm{C}$ for 3 days. The dried cancellous bone blocks were calcined at $800^{\circ} \mathrm{C}$ with a rate of $10^{\circ} \mathrm{C} /$ min and then maintained for $6 \mathrm{~h}$ to remove the organic matrix in a conventional $\mathrm{Ni}-\mathrm{Cr}$ coiled furnace.

Calcined bovine cancellous bone blocks were soaked in different concentrations of $0.01,0.02,0.03,0.04,0.05$, $0.06,0.07,0.08,0.09$, and $0.1 \mathrm{~mol} / 1$ of $\mathrm{Na}_{4} \mathrm{P}_{2} \mathrm{O}_{7} \cdot 10 \mathrm{H}_{2} \mathrm{O}$ solution, respectively, at $70^{\circ} \mathrm{C}$ for $24 \mathrm{~h}$. Since the surface of the immersed bone blocks contains superfluous immersion solution, a filter paper was used to sop up the redundant NP solution. Then the immersed bone blocks were dried at $70^{\circ} \mathrm{C}$ for 3 days. The calcined bovine cancellous bone blocks with different quantities of NP additions were sintered, which were placed on the platinum sheet and heated to different temperatures at a rate of $2.5^{\circ} \mathrm{C} / \mathrm{min}$ and maintained for $1 \mathrm{~h}$ in a SiC-heated furnace. The materials were cooled to room temperature by slow furnace cooling after heating.

\subsection{Evaluation and measurements}

The crystalline phases of specimens were determined by the Rigaku X-ray powder diffractometer with $\mathrm{CuK}_{\alpha}$ radiation and $\mathrm{Ni}$ filter at the speed of $4 \% \mathrm{~min}$. To determine phase contents, relative intensities of the main peaks of each phase were used. The FTIR spectra were recorded using $\mathrm{KBr}$ pellets $(1 \mathrm{mg}$ sample per $300 \mathrm{mg}$ $\mathrm{KBr}$ ) on a Jasco FTIR grating instrument with slow scan and normal silt width. The morphology and microstructure of the specimens were observed under the scanning electron microscope (SEM). The surface was coated with a thin layer of carbon of thickness of $2 \mu \mathrm{m}$, after being polished with diamond paste and after being etched with $0.1 \mathrm{~m} \mathrm{HCl}$ for about $10 \mathrm{~s}$. They were then observed by SEM and analyzed using an energy-dispersive electron probe $\mathrm{X}$-ray microanalyzer. $\mathrm{P}, \mathrm{Ca}$, and $\mathrm{Na}$ were analyzed across the grains and grain boundaries. An electron beam maintained at $2 \times 10^{-10} \mathrm{~A}$ was used and X-ray intensities in counts per second (cps) were recorded. The accelerating voltage was $12 \mathrm{kV}$.

\section{Results}

\subsection{Crystal structure analysis}

Figure 1 summarizes the XRD patterns of CBB heating at $1300^{\circ} \mathrm{C}$ with different NP additions. The CBB without NP addition showed a stoichiometric hydroxyapatite characterized pattern (XRD JCPDS data file No.9-432). As NP addition increased, the intensity of HAP characterized peaks gradually decreased and $\beta$ TCP 


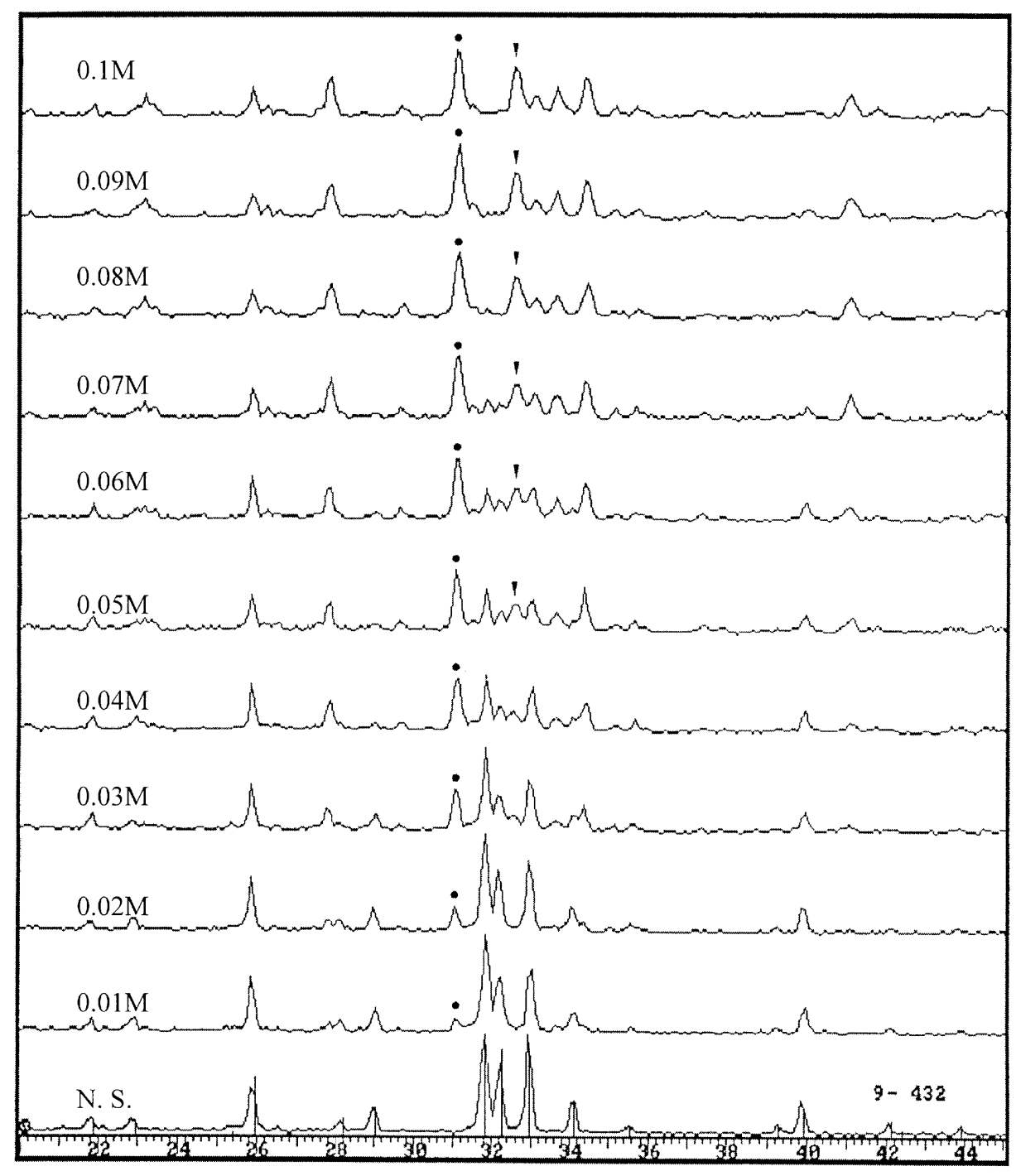

$2 \theta$ (degree)

Fig. 1. X-ray diffraction patterns of CBB soaked in different concentrations of NP solution and heated at $1300^{\circ} \mathrm{C}$

characterized peaks appeared progressively. When the concentration of the NP solution is in the range of 0.01-0.04 M, the XRD patterns showed a HAP/TCP biphasic structure where the crystalline phase of CBB was composed by HAP and TCP. Once the concentration of the NP solution is increased to $0.05 \mathrm{M}$, the rhenanite $\left(\mathrm{NaCaPO}_{4}\right)$ characterized peaks gradually appear and CBB forms a $\mathrm{HAP} / \mathrm{TCP} / \mathrm{NaCaPO}_{4}$ multiphasic structure. When the concentration of a NP solution is over $0.08 \mathrm{M}$, the HAP would completely transform into $\beta \mathrm{TCP}$ where all the characterized peaks of HAP would disappear. Only $\beta \mathrm{TCP}$ and $\mathrm{NaCaPO}_{4}$ characterized peaks existed in the system when the concentration of the NP solution was over $0.08 \mathrm{M}$ (Fig. 1).

To further understand the phase transformation of CBB with NP addition, the CBB with 0.05 m NP addi- tion was prepared and heated at different temperatures. Figures 2 and 3 showed the XRD patterns of CBB and CBB with $0.05 \mathrm{M} \mathrm{NP}$ addition, respectively, at different heating temperatures. As shown in Fig. 2, there were no significant differences in XRD patterns of $\mathrm{CBB}$ from room temperature to $1300^{\circ} \mathrm{C}$ where all the characterized peaks of the pattern were in agreement with the HAP XRD JCPDS data file (No. 9-432). After CBB was soaked in $0.05 \mathrm{M}$ NP solution for $24 \mathrm{~h}$ and then heated at different temperatures, the intensity of HAP characterized peaks in the pattern showed a negative tendency with heating temperature as shown in Fig. 3. It also shows that the characterized peaks of $\beta \mathrm{TCP}$ and $\mathrm{NaCaPO}_{4}$ start being traced from around $600^{\circ} \mathrm{C}$ (Fig. 3). As the heating temperature increased, the intensity of the characterized peaks for $\beta \mathrm{TCP}$ and $\mathrm{NaCaPO}_{4}$ gradually increased. As 


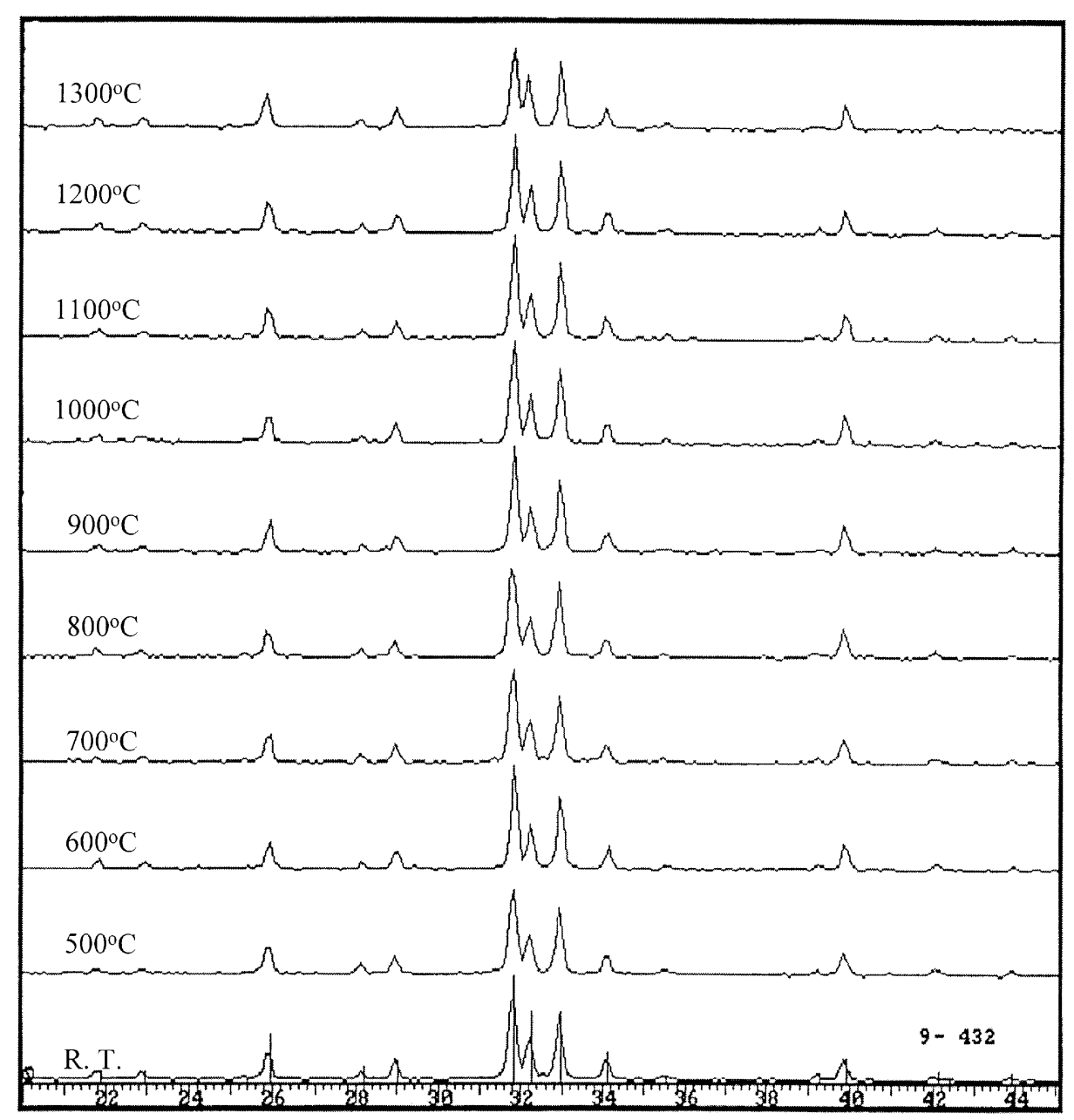

$2 \theta$ (degree)

Fig. 2. X-ray diffraction patterns of $\mathrm{CBB}$ heated from room temperature to $1300^{\circ} \mathrm{C}$.

the heating temperature is increased $1000^{\circ} \mathrm{C}$, the intensity of $\beta$ TCP characterized peaks still increases with heating temperature but the intensity of $\mathrm{NaCaPO}_{4}$ characterized peaks gradually decrease.

\subsection{FTIR spectra analysis}

The FTIR spectra of CBB heated at different temperatures are shown in Fig. 4. There are no significant differences in the FTIR spectra of CBB from room temperature to $900^{\circ} \mathrm{C}$. As the heating temperature is increased to $1000^{\circ} \mathrm{C}$, the band of $\mathrm{OH}^{-}$at $635 \mathrm{~cm}^{-1}$ gradually decreases in its intensity with increasing temperature and it disappears at around $1300^{\circ} \mathrm{C}$. The FTIR spectra of CBB with $0.05 \mathrm{M}$ NP addition heated from room temperature to $1300^{\circ} \mathrm{C}$ are shown in Fig. 5. The bands at 1185,925 and $720 \mathrm{~cm}^{-1}$ correspond to the NP functional group and the other bands belong to the HAP structure. The intensity of NP bands gradually decreased as the heating temperature is increased to $500^{\circ} \mathrm{C}$ and then disappeared around $900^{\circ} \mathrm{C}$. The $\mathrm{OH}^{-}$band of HAP also gradually decreased in its intensity while the heating temperature is increased to $800^{\circ} \mathrm{C}$. The bands at 1118 and $945 \mathrm{~cm}^{-1}$ corresponding to TCP were observed around $800^{\circ} \mathrm{C}$. The TCP bands appeared significantly at $1118,973,945,603,586,649$ and $540 \mathrm{~cm}^{-1}$ when the heating temperature is over $1100^{\circ} \mathrm{C}$.

\subsection{Microstructure and NP addition}

Figure 6a shows the SEM observation of the fracture surfaces of the bovine cancellous bone block after heating at $800^{\circ} \mathrm{C}$. Its surface and interior structure contains numerous interconnecting micropores. When the CBB block was soaked into NP solution, it would like a sponge absorb NP into the material uniformly (as seen in Fig. 6b). After being immersed in different concentrations of NP solution for $24 \mathrm{~h}$, the CBB increased in 


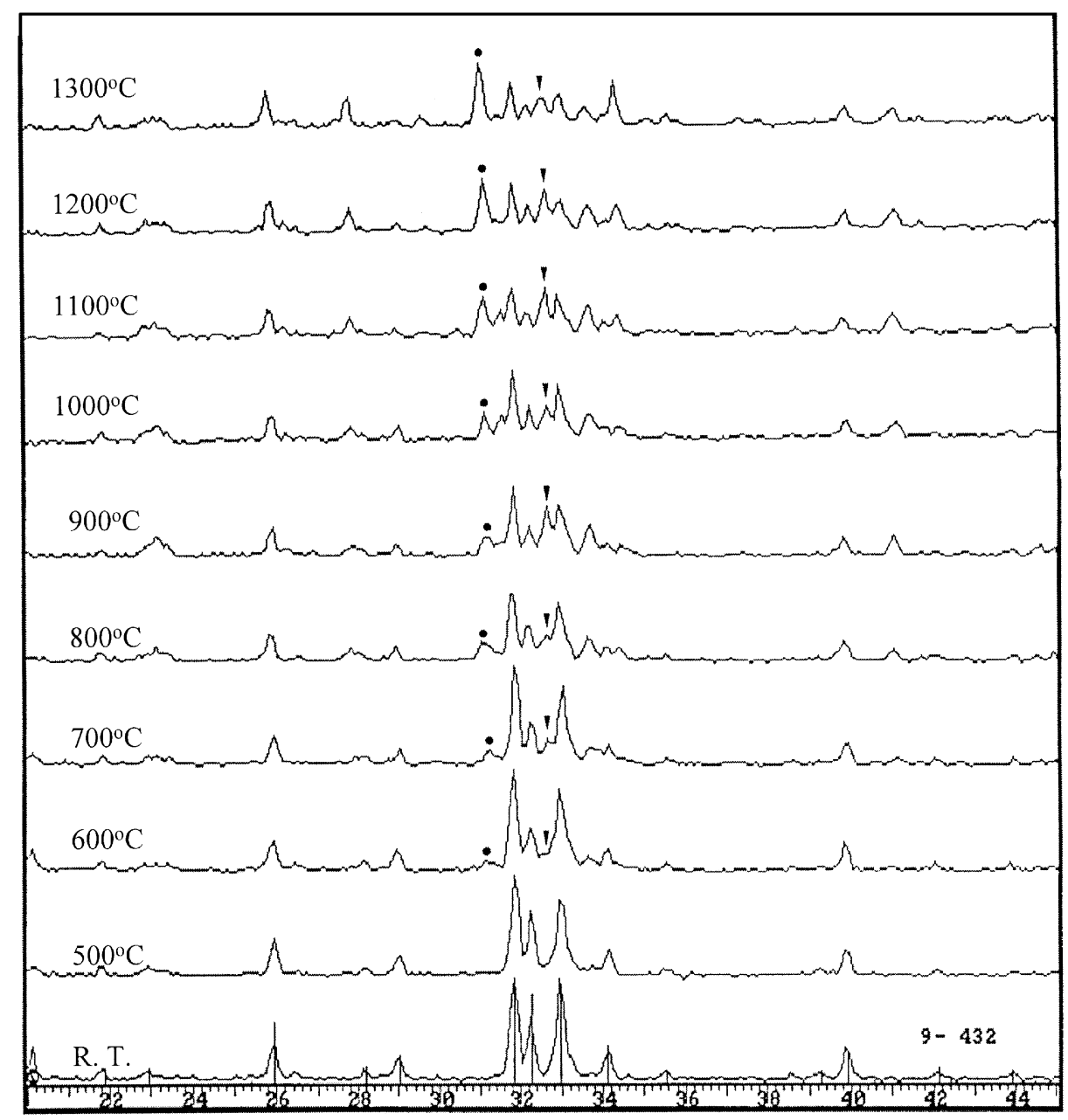

$2 \theta$ (degree)

Fig. 3. X-ray diffraction patterns of CBB soaked in $0.05 \mathrm{M} \mathrm{NP}$ solution and heated from room temperature to $1300^{\circ} \mathrm{C}$ (211)).

weight which was in terms of the content of NP in CBB. It showed that NP in CBB increases with the concentration of NP solution as shown in Fig. 7.

Figure 8 shows the SEM micrograph of the CBB with $0.03 \mathrm{M} \mathrm{NP}$ addition after heating at $1300^{\circ} \mathrm{C}$. Although the CBB has converted its crystalline constitution from pure HAP into TCP/HAP biphasic structure, it could also maintain the spongy structure of natural cancellous bone. As seen in its interior microstructure (Fig. 9a), the material was well-sintered and some of the original bony structures such as Haversian system, Volkmann's canals and lacunae could also be preserved. On etching with o. $1 \mathrm{M} \mathrm{HCl}$ solution, the sintered biphasic ceramic exhibited a polycrystalline structure with small grain size of about $1-2 \mu \mathrm{m}$ on average (Fig. 9b). Figure 10 shows the SEM microstructure of the trabecular section of CBB with $0.09 \mathrm{M} \mathrm{NP}$ addition after being heated at $1300^{\circ} \mathrm{C}$. It also shows a polycrystalline structure after being etched with $0.1 \mathrm{M} \mathrm{HCl}$, where two types of grain-shaped dendrites and granules could be clearly observed in the SEM micrographs of Fig. 10a and b, respectively. The dendrite was identified as $\mathrm{NaCaPO}_{4}$ by EPMA analysis and the granule was supposed to be $\beta$ TCP. The dentrite crystals were uniformly dispersed in TCP granules.

\section{Discussion}

In recent years, as a means of improving the biocompatibility of metal materials in vivo, coating HAP onto the metal implant surface using the plasma-spraying technique has been widely investigated [13-15]. To deposit HAP on a metal surface one should introduce HAP powder into a high-temperature flame, therefore, the thermal behavior of HAP has been gradually attracting 


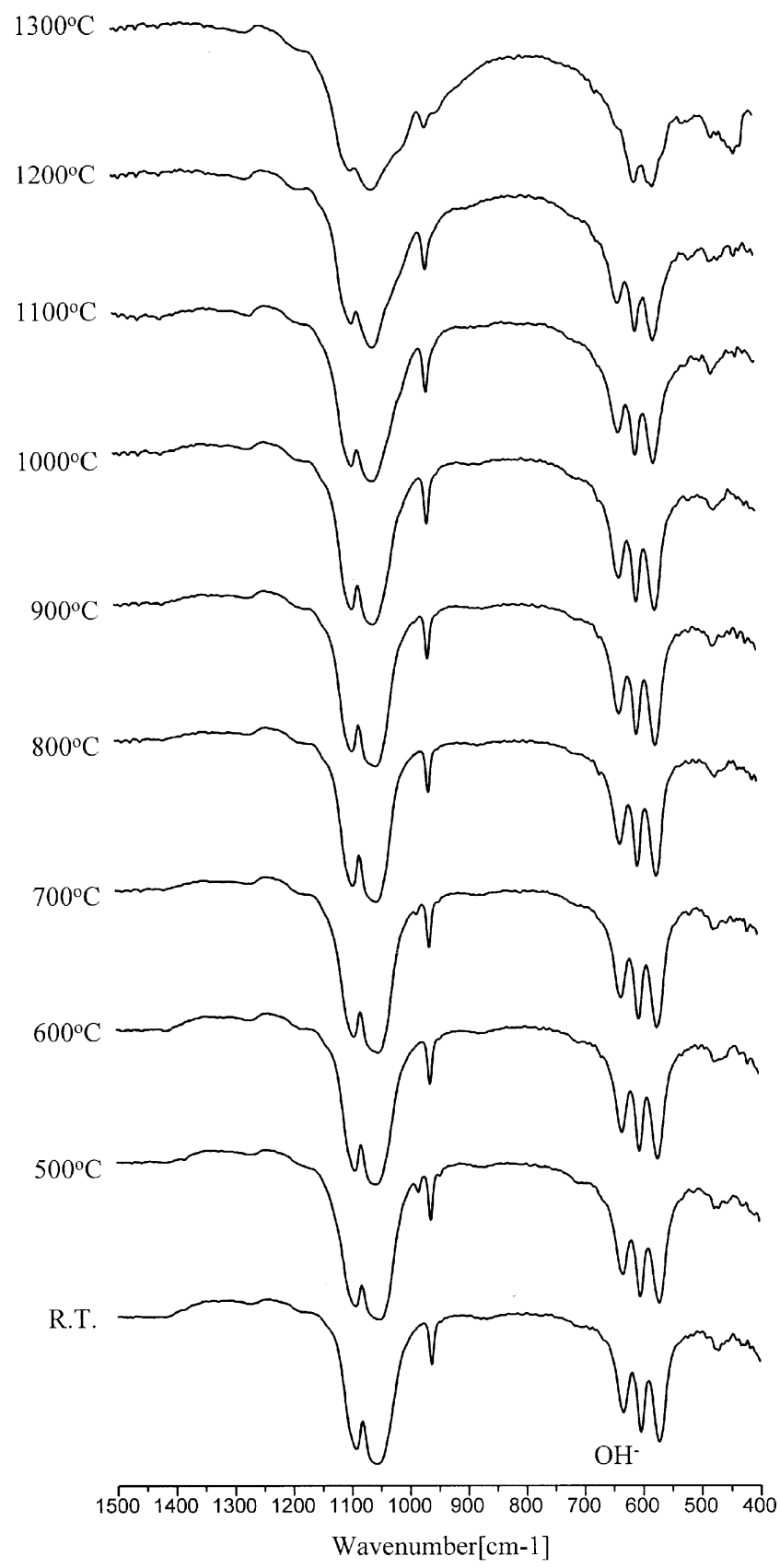

Fig. 4. FTIR spectra of CBB heated from room temperature to $1300^{\circ} \mathrm{C}$.

the attention of researchers. It is known that stoichiometric $\mathrm{HAP}$ releases its $\mathrm{OH}^{-}$ions and gradually transforms to oxyhydroxyapatite $\left(\mathrm{OHAP}, \mathrm{Ca}_{10}\left(\mathrm{PO}_{4}\right)_{6}(\mathrm{OH})_{2-2 X} \mathrm{O}_{X}\right)$ at temperatures up to $800^{\circ} \mathrm{C}[16]$ :

$\mathrm{Ca}_{10}\left(\mathrm{PO}_{4}\right)_{6}(\mathrm{OH})_{2} \rightarrow \mathrm{Ca}_{10}\left(\mathrm{PO}_{4}\right)_{6}(\mathrm{OH})_{2-2 X} \mathrm{O}_{X}+\mathrm{H}_{2} \mathrm{O}$

When OHAP is heated at high temperature, it will decompose into tricalcium phosphate and tetracalcium

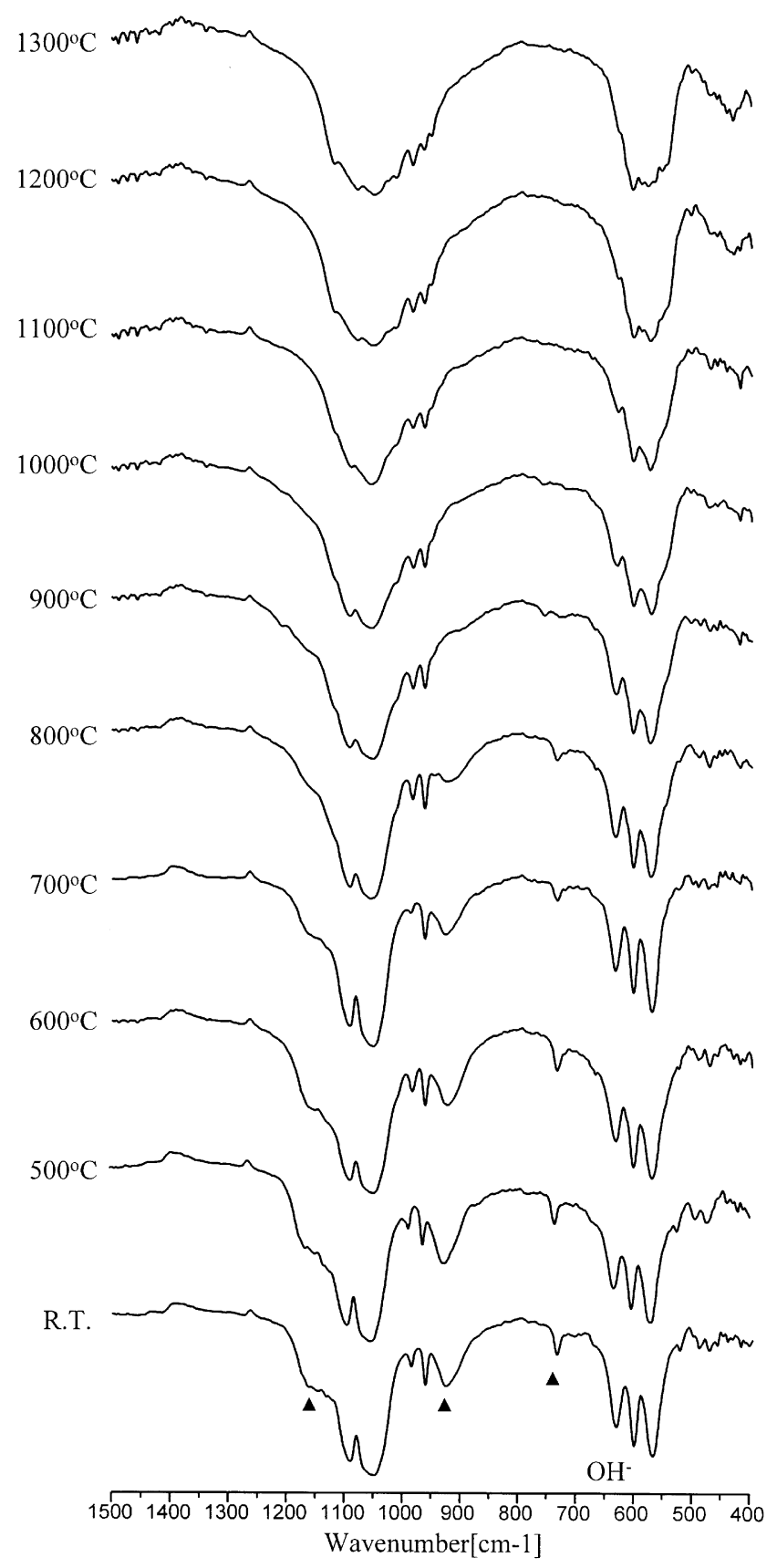

Fig. 5. FTIR spectra of CBB soaked in $0.05 \mathrm{M} \mathrm{NP}$ solution and heated from room temperature to $1300^{\circ} \mathrm{C}(\boldsymbol{\Delta}$ : bands of NP).

phosphate (TTCP, $\mathrm{Ca}_{4} \mathrm{P}_{2} \mathrm{O}_{9}$ ), which could be described as follows [17]:

$$
\mathrm{Ca}_{10}\left(\mathrm{PO}_{4}\right)_{6}(\mathrm{OH})_{2} \rightarrow 2 \mathrm{Ca}_{3}\left(\mathrm{PO}_{4}\right)_{2}+\mathrm{Ca}_{4} \mathrm{P}_{2} \mathrm{O}_{9}+\mathrm{H}_{2} \mathrm{O}
$$

The decomposition temperature of HAP has been reported to mainly depend on the atmosphere of heating. If performed under vacuum, HAP loses its $\mathrm{OH}^{-}$ions and decomposes into $\alpha \mathrm{TCP}$ and TTCP around $1125^{\circ} \mathrm{C}$. If HAP is heated in a $\mathrm{H}_{2} \mathrm{O}$ stream, the decomposition 

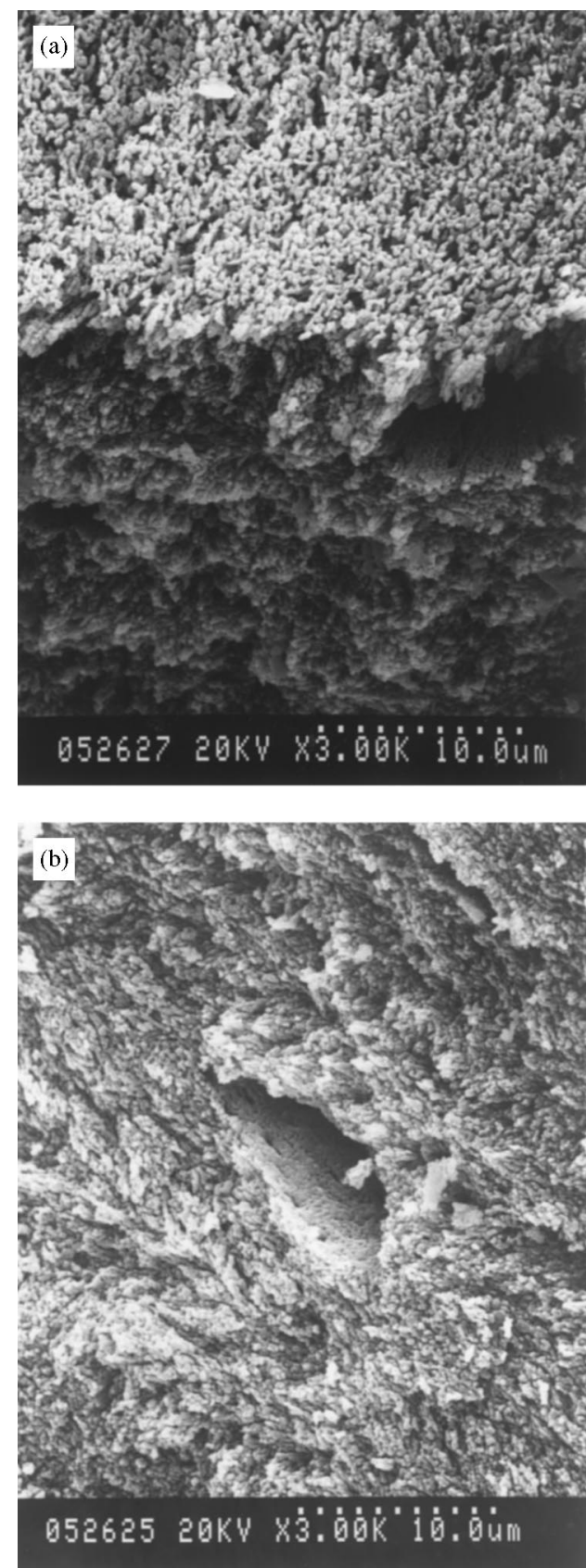

Fig. 6. The fracture surface of (a) CBB and (b) CBB soaked in $0.05 \mathrm{M}$ NP solution for $24 \mathrm{~h}$.

temperature of $\mathrm{HAP}$ will be raised up to $1400^{\circ} \mathrm{C}[13,14]$. In addition, the functional groups of HAP is also an important determinant factor for the decomposition temperature of HAP. Non-stoichiometric HAP, such as deficient HAP (d-HAP, $\left.\mathrm{Ca}_{10-X}\left(\mathrm{HPO}_{4}\right)_{X}\left(\mathrm{PO}_{4}\right)_{6-X}(\mathrm{OH})_{2-X}\right)$ has the same crystal structure as HAP, but its decomposition temperature is lower than HAP. Since the $\mathrm{HPO}_{4}^{2-}$ ions of d-HAP are condensed into $\mathrm{P}_{2} \mathrm{O}_{7}^{4-}$ $\left(2 \mathrm{HPO}_{4}^{2-} \rightarrow \mathrm{P}_{2} \mathrm{O}_{7}^{4-}+\mathrm{H}_{2} \mathrm{O}\right)$ in the temperature of $250^{\circ} \mathrm{C}$ to $550^{\circ} \mathrm{C}, \mathrm{P}_{2} \mathrm{O}_{7}^{4-}$ will then react with the $\mathrm{OH}^{-}$

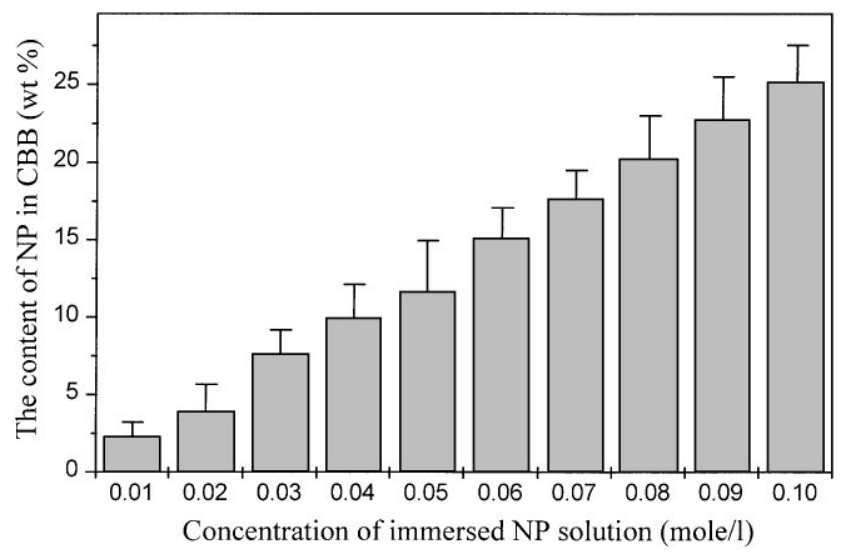

Fig. 7. Weight change of CBB block after being soaked in different concentrations of NP solution.

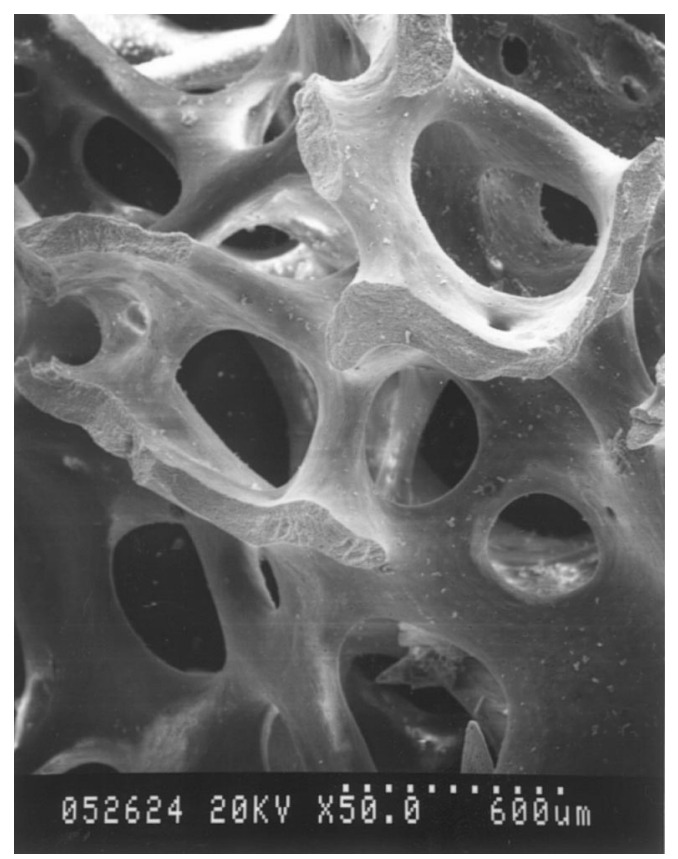

Fig. 8. SEM micrograph of the CBB soaked in $0.03 \mathrm{M} \mathrm{NP}$ solution and heated at $1300^{\circ} \mathrm{C}$.

ions of d-HAP as the following formula: $\mathrm{P}_{2} \mathrm{O}_{7}^{4-}+2 \mathrm{OH}^{-} \rightarrow 2 \mathrm{PO}_{4}^{3-}+\mathrm{H}_{2} \mathrm{O}$. It will lead to dHAP decomposed into $\beta$ TCP and HAP around $650^{\circ} \mathrm{C}$ $[18,19]$.

Crystallographic investigations of the bone minerals have shown that, apart from the main fraction exhibiting the base structure of HAP (containing stoichiometric HAP and non-stoichiometric HAP), bone contained other crystalline substances such as octacalcium phosphate $\left(\mathrm{Ca}_{8} \mathrm{H}_{2}\left(\mathrm{PO}_{4}\right)_{6} \cdot 5 \mathrm{H}_{2} \mathrm{O}, \mathrm{OCP}\right)$, brushite $\left(\mathrm{CaHPO}_{4} \cdot 2 \mathrm{H}_{2} \mathrm{O}, \mathrm{DCP}\right)$ and tricalcium phosphate [2]. Fowler [20] has studied the pyrolysis reactions of octacalcium phosphate. He showed that OCP and DCP 


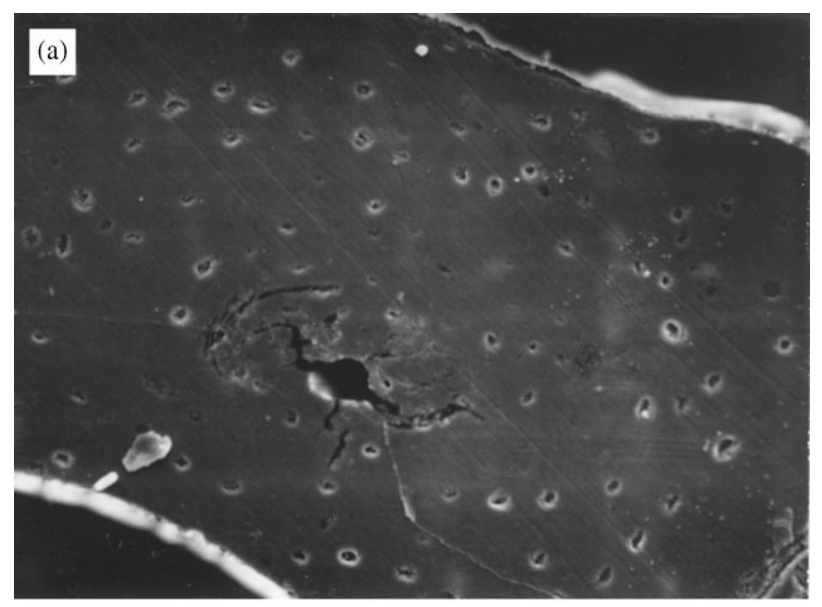

$\overline{44 \mu \mathrm{m}}$

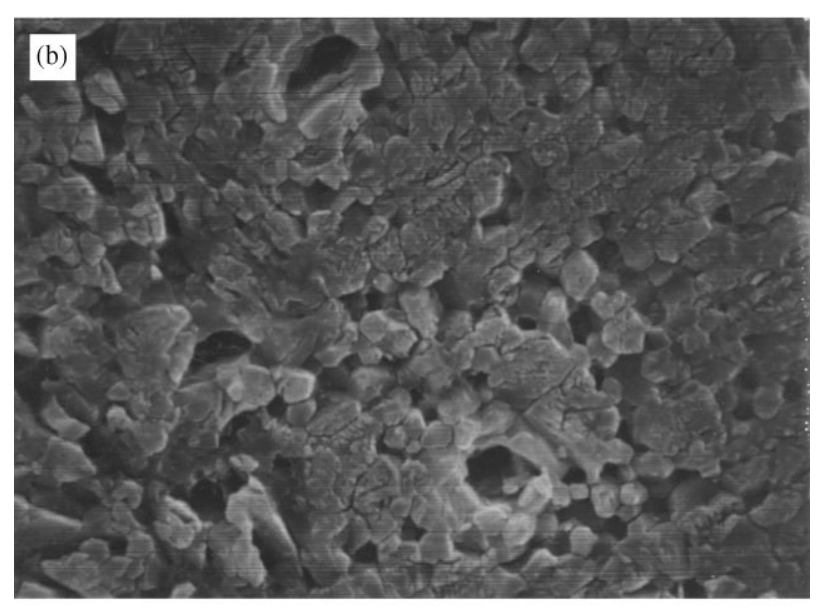

$\overline{4.4 \mu \mathrm{m}}$

Fig. 9. SEM micrographs of trabecular section of $\mathrm{CBB}$ after being soaked in $0.03 \mathrm{M} \mathrm{NP}$ solution for $24 \mathrm{~h}$ and heated at $1300^{\circ} \mathrm{C}$ : (a) original magnification $\times 230$; (b) original magnification $\times 2300$.

would be turned into calcium pyrophosphate $\left(\mathrm{Ca}_{2} \mathrm{P}_{2} \mathrm{O}_{7}\right)$ during heating, and calcium pyrophosphate could react with HAP of the bone to produce $\beta \mathrm{TCP}$ at a high temperature. Mittelmeier et al. [1,2] heated the bovine cancellous bone and found that the sintered bovine bone and contained $93 \%$ of hydroxyapatite (natural bone contains $90 \%$ ) and about $7 \%$ of tricalcium phosphate. In the present study, the sintered CBB exhibited a pure form of HAP crystalline structure. There were no significant differences in the XRD analysis when the heating temperature was raised from room temperature to $1300^{\circ} \mathrm{C}$. No TCP characterized peaks or other crystalline phases have been traced in the CBB (Fig. 4). The results of FTIR analysis (Fig. 6) shows that CBB has a thermal behavior similar to the stoichiometric HAP, which gradually releases its $\mathrm{OH}^{-}$ions and transforms to oxyapatite $\left(\mathrm{Ca}_{10}\left(\mathrm{PO}_{4}\right)_{6} \mathrm{O}\right)$ at high temperature.

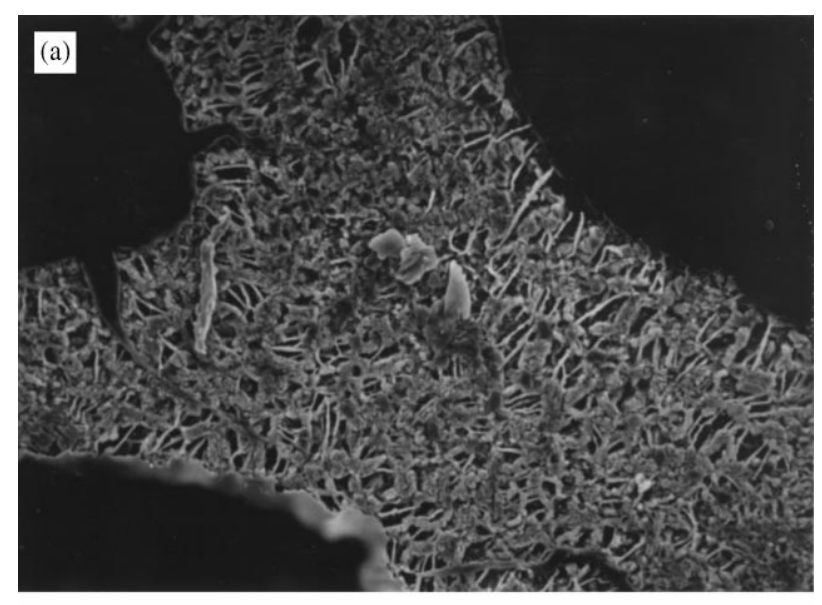

\section{$\overline{44 \mu \mathrm{m}}$}

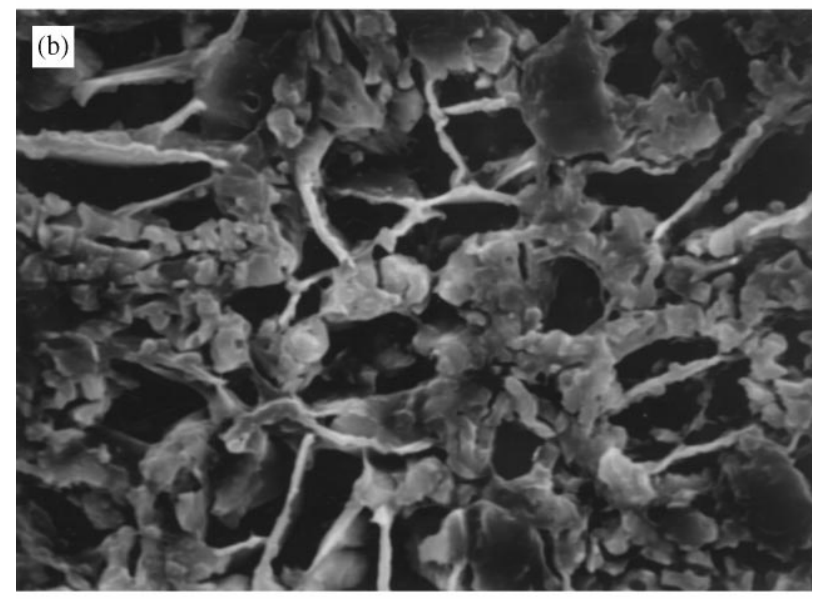

\section{$\overline{4.4 \mu \mathrm{m}}$}

Fig. 10. SEM photographs of trabecular section of $\mathrm{CBB}$ after being soaked in $0.09 \mathrm{M} \mathrm{NP}$ solution for $24 \mathrm{~h}$ and heated at $1300^{\circ} \mathrm{C}$ : (a) original magnification $\times 230$; (b) original magnification $\times 2300$.

In the previous study, d-HAP would decompose into $\mathrm{HAP}$ and $\beta \mathrm{TCP}$ around $650^{\circ} \mathrm{C}$ as follows:

$$
\begin{gathered}
\mathrm{Ca}_{10-X}\left(\mathrm{HPO}_{4}\right)_{X}\left(\mathrm{PO}_{4}\right)_{6-X}(\mathrm{OH})_{X} \rightarrow 3 X \mathrm{Ca}_{3}\left(\mathrm{PO}_{4}\right)_{2} \\
+(1-X) \mathrm{Ca}_{10}\left(\mathrm{PO}_{4}\right)_{6}(\mathrm{OH})_{2}+\mathrm{XH}_{2} \mathrm{O}
\end{gathered}
$$

After d-HAP is added to NP, it would raise the concentration of $\mathrm{P}_{2} \mathrm{O}_{7}^{4-}$ ions in the system. The foreign $\mathrm{P}_{2} \mathrm{O}_{7}^{4-}$ ions coming from NP would further react with HAP, decomposed from d-HAP, to produce more $\beta \mathrm{TCP}$ in the system. In this study, NP doped to the CBB could also react with HAP to produce some of the chemical compounds containing $\mathrm{PO}_{4}^{3-}$ ions, i.e. $\beta$ TCP. In Fig. 3, $\mathrm{NaCaPO}_{4}$ could be traced in the XRD patterns around $600^{\circ} \mathrm{C}$ because of much more $\mathrm{P}_{2} \mathrm{O}_{7}^{4-}$ ions contained in 
the system. The reaction of Eq. (4) might have happened in the system as follows:

$$
\begin{aligned}
& 3 \mathrm{Ca}_{10}\left(\mathrm{PO}_{4}\right)_{6}(\mathrm{OH})_{2}+2 \mathrm{Na}_{4} \mathrm{P}_{2} \mathrm{O}_{7} \rightarrow \\
& 8 \mathrm{Ca}_{3}\left(\mathrm{PO}_{4}\right)_{2}+6 \mathrm{NaCaPO}_{4}+\mathrm{Na}_{2} \mathrm{O}+3 \mathrm{H}_{2} \mathrm{O}
\end{aligned}
$$

The results of FTIR (Fig. 5) showed that the bands of $\mathrm{NP}$ disappeared around $900^{\circ} \mathrm{C}$. It reflected that the reaction of Eq. (4) might be completed at that temperature. When CBB with NP addition is heated over $900^{\circ} \mathrm{C}$, characteristic peaks of $\beta \mathrm{TCP}$ increased with the heating temperature but both peaks of $\mathrm{HAP}$ and $\mathrm{NaCaPO}_{4}$ showed a negative tendency with the heating temperature (Fig. 3). The authors speculated that HAP and $\mathrm{NaCaPO}_{4}$ will further react to form $\beta \mathrm{TCP}$ as the following formula:

$$
\begin{gathered}
\mathrm{Ca}_{10}\left(\mathrm{PO}_{4}\right)_{6}(\mathrm{OH})_{2}+2 \mathrm{NaCaPO}_{4} \rightarrow \\
4 \mathrm{Ca}_{3}\left(\mathrm{PO}_{4}\right)_{2}+2 \mathrm{NaPO}_{3}
\end{gathered}
$$

Santos et al. [21] indicated that additions of $\mathrm{Na}_{2} \mathrm{O}$ to the glass seems to be detrimental to the stability of HAP, giving rise to greater amounts of HAP transformed into TCP. Rey et al. [22] reported that, on heating to $1000^{\circ} \mathrm{C}$, some of the sodium ions may enter into the apatite structure containing vacancies on $\mathrm{OH}^{-}$sites leading to the imbalances in the $\mathrm{Ca} / \mathrm{P}$ ratio of HAP, which could also lead to the appearance of $\beta$ TCP. Kasgasnieni et al. [23] studied silicate-based glass matrices and found that the sodium ions could diffuse into the hydroxyapatite particle which then converted into $\mathrm{NaCaPO}_{4}$ and led to HAP decomposition. It is known from Fig. 3 that the system will produce a large amount of $\mathrm{NaCaPO}_{4}$ when heated up to $900^{\circ} \mathrm{C}$. Sodium ions could be detrimental to the stability of HAP and then $\mathrm{NaCaPO}_{4}$ might react with HAP to produce more $\beta \mathrm{TCP}$ in the system between 900 and $1300^{\circ} \mathrm{C}$.

Summarizing from Eqs. (4) and (5) it is known that NP doped into CBB could react with the HAP of CBB to produce $\beta \mathrm{TCP}$ and $\mathrm{NaCaPO}_{4}$ around $600^{\circ} \mathrm{C}$. At high temperature, the $\mathrm{NaCaPO}_{4}$ will further react with HAP to produce more $\beta \mathrm{TCP}$ in the system. Thus, while NP addition was lower in $\mathrm{CBB}$ such as in the condition of CBB soaked in NP solution with concentration in the range of $0.01-0.04 \mathrm{M}$, the product of the reaction of Eq. (4) $-\mathrm{NaCaPO}_{4}$ would be used up in the reaction of Eq. (5) at high temperature to form a HAP/TCP biphasic crystalline structure. At higher NP additions such as the CBB soaked in NP solution with the concentration of 0.05-0.07 M, the residual $\mathrm{NaCaPO}_{4}$ will be left in the system to form a $\mathrm{HAP} / \mathrm{TCP} / \mathrm{NaCaPO}_{4}$ multiphasic crystalline structure. If $\mathrm{CBB}$ is soaked in an NP solution with a concentration over $0.08 \mathrm{M}$, HAP will completely react and form a TCP $/ \mathrm{NaCaPO}_{4}$ biphasic structure.

$\mathrm{NaCaPO}_{4}$ has higher solubility which has been used as a phosphate fertilizer [24]. Kangasniemi et al. [23] sug- gested that $\mathrm{NaCaPO}_{4}$ was as bioactive as HAP but exhibited a higher extent of dissolution in body environment. Ramselaar et al. [25] reported that $\mathrm{NaCaPO}_{4}$ appeared to transform into an apatite containing carbonate, sodium and magnesium while it was inserted in tooth sockets of beagle dogs for six months. Thus, from the biological point of view $\mathrm{NaCaPO}_{4}$ has similar biodegradable properties with TCP, if HAP ceramic contains $\mathrm{NaCaPO}_{4}$, the high solubility of $\mathrm{NaCaPO}_{4}$ could also improve the bioactivity of HAP in vivo. Additionally, $\mathrm{NaCaPO}_{4}$ has higher solubility than TCP [26], we could develop a new bioresorbable ceramic which has a higher bioresorbability than TCP ceramic, i.e. TCP $/ \mathrm{NaCaPO}_{4}$ ceramic or $\mathrm{NaCaPO}_{4}$ ceramic by heating $\mathrm{CBB}$ with high NP addition.

\section{Conclusion}

In the present study, the CBB exhibited a pure form of HAP characterized patterns, there were no other crystalline phases to be traced during heating. The thermal behavior of CBB was similar with stoichiometric HAP, which loses its $\mathrm{OH}^{-}$ions and gradually transforms into oxyhydroxyapatite at high temperature. NP doped into $\mathrm{CBB}$ could react with HAP of calcined bone to produce $\beta \mathrm{TCP}$ and $\mathrm{NaCaPO}_{4}$ around $600^{\circ} \mathrm{C}$. At $900^{\circ} \mathrm{C}$, NP addition would be used up and the $\mathrm{NaCaPO}_{4}$ could further react with HAP to produce more $\beta \mathrm{TCP}$ in the system.

The crystalline phase composition of $\mathrm{CBB}$ could be changed by doping with different contents of NP in CBB and heated at high temperature. As the NP addition increases, the phase composition of CBB would gradually transform from stoichiometric HAP to HAP/TCP, $\mathrm{HAP} / \mathrm{TCP} / \mathrm{NaCaPO}_{4}$ or $\mathrm{TCP} / \mathrm{NaCaPO}_{4}$. We could utilize this process to prepare different crystalline phase compositions with a natural bone structure.

\section{References}

[1] Urist MR, O`Connor BT, Burwell RG. Bone grafts, derivatives and substitutes. London: Butterworth-Heinemann, 1994.

[2] Katthagen BD. Bone regeneration with bone substitutes. Boca Raton, FL: CRC Press, 1983.

[3] Maatz R. A new method of bone maceration. J Bone Jt Surg 1957; 39A:153-66.

[4] Maatz R, Lenz W, Graf R. Spongiosa test of bone grafts for transplantation. J Bone Jt Surg 1954;36A:721-31.

[5] Salama R. Xenogeneic bone grafting in humans. Clin Orthop 1983;174:113-21.

[6] Salama R, Gazit E. The antigenicity of Kiel bone in the human host. J Bone Jt Surg 1978;60B:262-5.

[7] Aoki H. Medical application of hydroxyapatite. Ishiyaku Euro America Inc., Tokyo, St. Louis: Takayama Press, 1994.

[8] Jarcho M. Calcium phosphate ceramics as hard tissue prosthetics. Clin Orthop Relat Res 1981;157:259-78. 
[9] de Groot K. Bioceramics of calcium phosphate. Boca Raton, FL: CRC Press, 1983.

[10] Kohri M, Miki K, Waite DE, Nakajima H, Okabe T. In vivo stability of biphasic calcium phosphate ceramics. Biomaterials 1993;14:299-304.

[11] Frayssinet P, Trouillet JL, Rouquet N, Azimus E, Autefage A. Osseointegration of macroporous calcium phosphate ceramics having a different chemical composition. Biomaterials 1993; 14:423-9.

[12] Nery EB, LeGeros RZ, Lynch KL, Lee K. Tissue response to biphasic calcium phosphate ceramic with different ratios of HA $/ \beta$ TCP in periodontal osseous defects. J Periodontol 1992; 63:729-35.

[13] Locardi B, Pazzaglia UE, Gabbi C, Profilo B. Thermal behaviour of hydroxyapatite intended for medical applications. Biomaterials 1993;14:437-441.

[14] Ellies LG, Nelson DG, Featherstone JD. Crystallographic changes in calcium phosphates during plasma-spraying. Biomaterials 1992;13:313-6.

[15] Chen J, Tong W, Yang C, Feng J, Zhang X. Effect of atmosphere on phase transformation in plasma-sprayed hydroxyapatite coatings during heat treatment. J Biomed Mater Res 1997;34:15-20.

[16] Trombe JC, Montel G. Some features of the incorporation of oxygen in different oxidation states in the apatitic lattice-II. J Inorg Nucl Chem 1977;40:23-6.

[17] Jiming Z, Zhang X, Xingdong C, Jiyong Z, Shaoxian, de Groot K. High temperature characteristics of synthetic hydroxyapatite. J Mater Sci: Mater Med 1993;4:83-5.
[18] Ishikawa K, Ducheyne P, Radin S. Determination of the $\mathrm{Ca} / \mathrm{P}$ ratio in calcium-deficient hydroxyapatite using $\mathrm{X}$-ray diffraction analysis. J Mater Sci: Mater Med 1993;4:165-8.

[19] Yubao L, Klein CPAT, de Wijn J, Van de Meer S. Preparation and characterization of nanograde osteoapatite-like rod crystals. J Mater Sci: Mater Med 1994;5:252-5.

[20] Fowler BO, Moreno EC, Brown WE. Infra-red spectra of hydroxyapatite, octacalcium phosphate and pyrolysed octacalcium phosphate. Arch Oral Biol 1966;11:477-92.

[21] Santos JD, Knowles JC, Reis RL, Monteiro FJ, Hastings GW. Microstructural characterization of glass-reinforced hydroxyapatite composites. Biomaterials 1994;15:5-10.

[22] Rey C, Trombe JC, Montel G. Retention of molecular oxygen by the lattice of certain alkaline earth apatites. C R Acad Sci Ser C 1973;276:1385-8.

[23] Kangasniemi I, de Groot K, Wolke J, Andersson O, Luklinska Z, Becht JGM, Lakkisto M, Yli-Urpo A. The stability of hydroxyapatite in an optimized bioactive glass matrix at sintering temperature. J Mater Sci: Mater Med 1991;2:133-7.

[24] Ando J, Matsuno S, $\mathrm{Ca}_{3}\left(\mathrm{PO}_{4}\right)_{2}-\mathrm{CaNaPO}_{4}$ system. Bull Chem Soc Jpn 1968;41:342-7.

[25] Ramselaar MMA, van Mullem PJ, Kalk W, Driessens FCM, de Wijn JR, Stols ALH. In vivo reactions to particulate rehenanite and particulate hydroxyapatite after implantation in tooth sockets. J Mater Sci-Mater Med 1993;4:311-7.

[26] Berger G, Gildenhaar R, Ploska U. Rapid resorbable, glassy crystalline materials on the basic of calcium alkali orthophosphates. Biomaterials 1995;16:1241-8. 